\title{
MENINGKATKAN KEMAMPUAN MENYELESAIKAN MASALAH BELAJAR SISWA SMK DENGAN LAYANAN BIMBINGAN TEKNIK PROBLEM-BASED INTRODUCTION
}

\author{
Wijayanti \\ SMK Negeri 2 Kediri \\ Email: wijayanti.sh@gmail.com
}

\section{ABSTRACT}

The ability to solve vocational student learning problems is an important element in achieving optimal learning achievement and everyday life. The importance of this ability is not yet optimal among SMK students. To improve these capabilities, researchers need to use classical guidance services with problem-based introduction techniques that are relevant to the abilities to be achieved. Thus the purpose of this study is to find out the application of guidance services with problem-based introduction techniques to improve the ability to solve vocational student learning problems. To achieve this goal, researchers used the action research method in BK (PTBK) for two cycles of 50 students, drawn from a population of 2004 vocational school students by purposive sampling. The results of this study indicate the achievement of criteria as much as $46 \%$ in the first cycle, and the remaining $64 \%$ was achieved in the second cycle. With this achievement, it can be concluded that the guidance service with problem-based introduction techniques can be applied to improve the ability to solve vocational student learning problems.

\begin{abstract}
ABSTRAK
Kemampuan menyelesaikan masalah belajar siswa SMK merupakan elemen penting dalam pencapaian prestasi belajar yang optimal dankehidupan sehari-hari. Pentingnya kemampuan ini belum optimal pada kalangan siswa SMK. Untuk meningkatkan kemampuan tersebut peneliti perlu menggunakan layanan bimbingan klasikal dengan teknik problem-based introduction yang relevan dengan kemampuan yang ingin dicapai. Dengan demikian tujaun penelitian ini adalah untuk mengetahi penerapan layanan bimbingan dengan teknik problem-based introduction untuk meningkatkan kemampuan menyelesaikan masalah belajar siswa SMK. Untuk mencapai tujuan, peneliti menggunakan metode penelitian tindakan dalam BK (PTBK) sebanyak 2 siklus pada 50 siswa, yang diambil dari populasi sebanyak 2004 siswa SMK secara purposive sampling. Hasil penelitian ini menunjukan ketercapaian kriteria sebanyak $46 \%$ pada siklus pertama dan sisanya $64 \%$ dicapai pada siklus kedua. Dengan ketercapaian itu dapat disimpulkan bahwa layanan bimbingan dengan teknik problem-based introduction dapat diterpkan untuk meningkatkan kemampuan menyelesaikan masalah belajar siswa SMK.
\end{abstract}

Keywords

Academic

problems, problemsolving ability, guidance service, problem-based introduction

Kata Kunci Masalah belajar, kemampuan pemecahan masalah, layanan bimbingan, problem-based introduction

Cara mengutip: Wijayanti, W. (2020). Meningkatkan Kemampuan Menyelesaikan Masalah Belajar Siswa SMK Dengan Layanan Bimbingan Teknik Problem-Based Introduction. Nusantara of Research : Jurnal Hasil-Hasil Penelitian Universitas Nusantara PGRI Kediri (e-Journal), 6(2), 115-124. https://doi.org/10.29407/nor.v6i2.13633 


\section{PENDAHULUAN}

Proses belajar merupakan proses yang dilakukan secara sardar oleh individu dalam memperoleh perubahan aspek tertentu yang relatif menetap (Hitipeuw, 2009). Dalam belajar seorang individu haruslah melibatkan berbagai kondisi baik internal maupun eksternal dalam mencapai perubahan. Meskipun demikian pelaksanaan belajar oleh siswa tidak selalu berjalan secara ideal. Siswa sering kali tidak lepas dari berbagai tantangan dan masalah yang begitu saja muncul. Masalah tersebut dapat berasal dari dalam diri siswa atau juga berasal dari luar diri siswa tersebut. Hal yang bersaal dari dalam misalnya kurangnya kemampuan psiko-fisik siswa, yang meliputi aspek kognitif, aspek afektif, dan aspek psikomotorik. Rendahnya ranah cipta (inteligensi) akan berpengaruh pada prestasi belajar siswa. Demikian halnya dengan ranah rasa, dan ranah karsa. Labilnya emosi dan sikap, serta gangguan indera penglihatan dan pendengaran akan memberikan pengaruh dalam belajar. Sedangkan faktor dari luar seperti suasana pembelajaran dikelas, iklim atau cuaca, penyampaian dan metode yang diberikan guru dan lain sebagainya.

Majid (2008) menjelaskan bahwa masalah belajar adalah suatu kondisi tertentu yang dihadapi oleh seseorang murid dan menghambat kelancaran proses belajaranya. Kondisi tertentu yang dimaksud disini adalah sesuatu yang berhubungan dengan diri siswa, yaitu berupa kelemahan-kelemahan yang dimilikinya dan dapat juga berhubungan dengan lingkungan yang tidak menguntungkan bagi dirinya. Selanjutnya Majid (2008), juga menjelaskan bahwa masalah belajar dapat digolongkan atas, (1) sangat cepat dalam belajar, (2) keterlambatan akademik, (3) lambat belajar, (4) penempatan kelas, (5) kurang motif dalam belajar, (6) sikap dan kebiasaan buruk, dan (7) kehadiran di sekolah.

Untuk mengatasi berbagai masalah tersebut maka siswa haruslah memiliki kemampuan penyelesaina masalah. Kemampuan menyelesaikan masalah merupakan salah satu dari kemampuan berfikir tingkat tinggi ditinjau dari hirarki belajar (Dahar, 1998) atau akhirakhir ini dikenal dengan HOTS. Siswa yang memiliki kemampuan berfikir tingkat tinggi akan membuat mereka kritis dan mudah memahami permasalahan yang mereka temui (Afflerbach, cho, \& Kim, 2015). Dengan problem solving kemampuan berfikir kritis siswa SMK juga dapat ditingkatkan (Safitri, Atrup, \& Hanggara, 2018). Dengan demikian dikatakan bahwa, kemampuan ini merupakan kemampuan penting yang harus dimiliki oleh siswa untuk menghadapai berbagai tantangan yang ada dalam kelangsungan belajarnya di sekolah dan dalam kehidupan seharihari. Karena sekolah merupakan miniatur dari masyarakat, maka kemampuan daklam menyekesaikan berbagai permasalahan yang ada dalam kegiatan belajar-mengajar di sekolah kemudian dapat diterapkan dalam kehidupan sehari-hari dimasyarakat.

Dalam bidang karir, kemampuan menyelesaiakan masalah begitu dibutuhkan dalam menentukan arah studi dan karir dimasa mendatang. Begitu juga dalam bidang social, kemampuan menyelesaikan masalah yang berhubungan dengan teman dan orang lain amatlah dibutuhkan mengingat manusia tidak lepas dari interaksinya dengan orang lain. Dalam bidang pribadi kemampuan menyelesaikan masalah yang berkaitan dengan gejolak internal merupakan hal penting dan pokok untuk mendapatkan ketentraman dan perkembangan yang 
optimal. Begitu juga dalam kegiatan belajar, kemampuan menyelesaikan masalah belajar siswa begitu penting agar dapat belajar dengan hasil yang optimal.

Kemampuan menyelesaikan masalah dalam belajar dapat mendukung kelancaran belajar siswa. Siswa yang berhasil menyelesaikan setiap tantangan dan masalah dalam belajar akan mendapatkan pengalaman yang lebih dan hasil belajar yang penuh dengan makna. Selain itu dengan berhasilnya siswa dalam menyelesaikan masalah dalam belajar siswa akan mendapatkan kepuasan tersendiri yang menjadikan iya lebih tertantang untuk naik ke level tantangan belajar yang lebih tinggi. Jika sudah terjadi kondisi yang demikian maka motivasi belajar dan berprestasi siswa akan meningkat sehingga hasil belajar akan lebih optimal.

Sayangnya menurut pengamatan peneliti, kemampuan menyelesaikan masalah belajar siswa SMK masih butuh untuk ditingkatkan. Rendahnya nilai pelajaran khususnya yang sifatnya teoritis merupakan indikasi bahwa siswa SMK memiliki kemampuan penyelesaian masalah belajar yag rendah. Indikasi tidak langsung dari rendahnya kemampuan penyelesaian masalah siswa adalah, energi siswa tidak lagi dicurahkan pada kegiatan dan prestasi belajar siswa, tetapi pada hal-hal lain yang justru dapat mengganggu kegiatan sekolah seperti mebolos, main game online atau main game playstation dan lain-lain. Hal-hal tersebut terjadi karena siswa merasa tidak ada kebanggaan dan kepuasan dalam belajar mereka. Siswa-siswa kurang terampil dalam menyelesaikan masalahnya dan bahkan tidak tahu apa yang perlu dilakukan untuk keluar dari masalahnya. Sehingga menjadikan mereka melakukan hal-hal yang dapat merugikan prestasi belajar mereka.

Kemampuan menyelesaikan masalah belajar ini merupakan hal yang tidak diajarkan secara khusus disekolah, padahal ini merupakan kemampuan dan keterampilan penting dalam kesuksesan belajar siswa. Terlebih usia SMK merupakan jenjang perkembangan yang ideal untuk mengembangkan kemampuan dalam menyelesaikan masalah siswa. Kemampuan menyelesaikan masalah siswa yang tidak diajarkan secara khusus ini biasanya dibebankan pada konselor atau guru BK yang justru memiliki pekerjaan yang kompleks dan banyak. Meskipun demikian upaya guru BK atau konselor haruslah tetap dilakukan dengan penuh tanggung jawab, mengigat pentingnya kemampuan dan keterampilan ini pada perkembangan siswa.

Salah satu layanan yang dipandang tepat dalam membantu siswa meningkatkan kemampuan dalam menyelesaikan masalah adalah dengan layanan bimbingan kelompok atau klasikal. Penggunaan layanan ini memiliki kelebihan yaitu dapat menjangkau siswa secara lebih luas dan memerlukan waktu yang lebih efisien. Hal yang terpenting adalah, adanya wadah yang memungkinkan siswa untuk saling berinteraksi, berdiskusi dan bertukar pengalaman tentang penyelesaian masalah siswa yang menjadikan belajar menjadi lebih efektif.

Adapaun teknik yang dipandang sitematis dan terstruktur untuk mengembangkan kemampuan penyelesaian masalah siswa adalah dengan teknik problem-based introduction $(P B I)$. Teknik ini merupakan suatu teknik pembelajaran berbasis masalah yang dihadapi siswa. Arends dalam Mustaji (2018) mengidentifikasi lima karakteristik pembelajaran berbasis masalah ini, antara lain pengajuan pertanyaan atau masalah, keterkaitan dengan disiplin ilmu, menyelidiki masalah autentik, memamerkan hasil kerja dan kolaborasi. Berbasis pada karakteristik tersebut, teknik PBI ini 
dilakukan dengan (1) Konselor menjelaskan tujuan layanan bimbingan yang dilakukan, (2) Konselor memotivasi siswa yang memiliki masalah (3) Konselor membantu siswa mengorganisasi pemecahan masalah sesuai dengan permasalahan siswa, (4) Konselor membantu siswa dalam membuat perencanaan dan membuat laporan, (5) Konselor membantu siswa dalam menyusun refleksi atau melakukan evaluasi setiap proses kegiatan yang dilakukan. Melalui bimbingan dengan pendekatan masalah, diharapkan siswa dapat mengidentifikasi masalah yang dihadapi, dan dengan potensi yang dimiliki siswa dapat memecahkan masalahnya. Lebih lanjut mereka dapat mengatasi masalah belajarnya.

Teknik ini dipilih karena menurut Nora (2011) PBI cocock untuk pengajaran yang memberikan kesempatan untuk aktif, memberikan pengalaman langsung dan berfikir kritis berdasarkan masalah yang terjadi disekitar. Fauziah (2017) juga telah membuktikan bahwa dengan pendekatan creative problem solving dapat meningkatkan kemampuan pemecahan masalah matematis siswa, khususnya dalam penelitian ini adalah siswa SMK. Dengan teknik ini maka siswa akan belajar tentang bagaiamana mengkaji berbagai masalah yang ada disekitarnya lalu secara kritis, siswa tersebut akan belajar mencari solusi dari permasalahan tersebut. Dengan pembiasaan untuk menghadapi masalah dan mencari solusinya maka siswa akan terbiasa dan responsive terhadap berbagai masalah yang mungkin timbul dalam kehidupannya.

Teknik PBI ini dirasa juga cocok yang menjadikan siswa lebih aktif, karena siswa tidak lagi disuplay materi yang membosankan. Dengan teknik ini menurut Sugiyanto (2009) fungsi pendidik akan lebih sebagai pembimbing dan fasilitator. Senjaya (2008) menuturkan lebih lanjut bahwa peran sebagai fasilitator pendidilk lebih pada melayani siswa agar mereka lebih mudah dalam belajar. Jika diaplikasikan dalam layanan bimbingan maka konselor akan memfasilitasi kebutuhan siswa agar lebih kritis dan terampil dalam menyelesaikan berbagai permasalahan.

Selain dari sisi kelebihan yang dimiliki oleh teknik PBI ini, berdasarkan penelususran referensi yang dilakukan terkait dengan penerapan model ini dalam bimbingan khususnya dalam meningkatkan kemampuan menyelesaikan masalah belajar siswa masih jarang ditemui. Berdasarkan urgensi dari penelitian yang dipaparkan diatas maka dapat dirumuskan tujuan dalam penelitian ini yaitu untuk mengetahui penerapan layanan bimbingan dengan teknik problem-based introduction untuk meningkatkan kemampuan menyelesaikan masalah belajar siswa SMK.

\section{METODE}

Berdasarkan tujuan penelitian yang hendak dicapai maka peneliti menggunakan model penelitian tindakan dalam bimbingan (PTBK). Penelitian ini menggunakan subyek penelitian yaitu siswa SMKN 2 Kediri. Jumlah keseluruhan populasi dalam penelitian ini adalah sebanyak 2004 siswa. Sampel penelitian dipilih secara purposive, yaitu siswa kelas X-MM1, XMM2, X-TKJ1, X-TKJ2, dan X-PM2 yang menjadi tanggung jawab peneliti dan menduduki peringkat 20\% dikelas dari hasil belajar semester 2 tahun pelajaran 2018/2019 yaitu sebanyak 50 siswa. Dari layanan bimbingan yang direkomendasaikan, penelitia memilih layanan bimbingan klasikal karena telah terkondisikan (terjadwal) kegiatanya atau secara natural siswa sudah terkondisikan. Disamping itu layanan bimbingan klasikal memiliki cakupan layanan yang lebih luas dan dapat mengakomodir seluruh siswa yang terpilih menjadi sampel penelitian 
tersebut. Dalam menerapkan model penelitian ini, peneliti berusaha menerapkan tahapan penelitian yang paparkan oleh Arikunto, (2006) sebagaimana dalam gambar berikut:

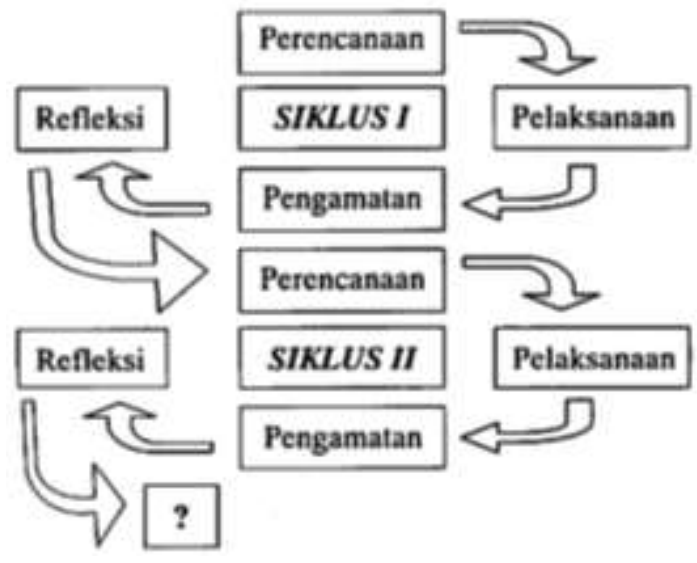

Gambar 1. Siklus Penelitian Tindakan

Tahap Perencanaan, dalam kegiatan penelitian ini meliputi kegiatan (a) penyusunan rancangan penelitian, (b) penjajagan dan penyempurnaan rancangan penelitian, (c) melakukan komunikasi dan koordinasi dengan Guru Bimbingan Konseling, Wali Kelas, Kepala Sekolah, dan Tenaga Kependidikan lainnya di SMK Negeri 2 Kediri, (d) Menyiapkan piranti (alat), dan instrument-instrumen yang diperlukan dalam penelitian, dan (e) Penjajagan subyek penelitian. Rancangan penelitian dimaksudkan sebagai pedoman awal bagi peneliti sebelum melakukan kegiatan penelitian. Sebelum dilakukan penelitian rancangan penelitian perlu dilakukan penjajagan. Penjajagan dilakukan dengan mengkomunikasikan rancangan penelitian dengan sesama guru bimbingan konseling, dengan wali kelas, dan dengan Kepala Sekolah.

Pada tahap pelaksanaan ini peneliti melaksanakan kegiatan layanan sesuai dengan rencana yaitu menggunakan layanan bimbingan dengan teknik problem-based introduction. $\mathrm{PBI}$ ini dilakukan dengan menyajikan masalah, mengajukan pertanyaan dan memfasilitasi penyelidikan serta dialog/ diskusi. Dengan menyajikan masalah maka siswa akan dapat megenali masalah yang dihadapi, mengidentifikasi faktor penyebab, mengorganisir masalah, membuat perencanaan dengan baik dan benar sesuai dengan masalah, tujuan, serta kemampuan yang dimiliki siswa.

Pada tahap pengamatan, konselor/ peneliti melakukan perekaman data tentang pelaksanan bimbingan dengan teknik PBI. Perekaman data dilakukan dengan metode observasi yang bertujuan untuk mengamati ketercapaian kriteria dalam penerapan teknik PBI ini. Dengan observasi konselor dapat mengamati proses dari pelaksanaan PBI dan juga mengamati hasil dari penyelenggaraan kegiatan ini.

Selanjutnya adalah tahap refleksi, dimana pada tahap ini konselor akan melakukan analisis dan evaluasi dari data yang diambil pada tahap sebelumnya. Melalui tahap refleksi ini akan diketahui ketercapaian dari penerapan PBI dalam meningkatkan kemampuan menyelesaikan masalah belajar siswa. Seberapa jauh kriteria yang telah tercapai akan memberikan keputusan apakah siklus penelitian ini berhenti karena dianggap cukup, ataukah dilanjutkan ke siklus selanjutnya karena dirasa belum cukup dalam mencapai kriteria yang diinginkan. Adapun kriteria yang ditetapkan oleh peneliti yaitu: jika kurang dari $50 \%$ siswa belum 
dapat melaksanakan tugas, maka indikator belum tercapai. sebaliknya, jika lebih dari 50\% siswa dapat melaksanakan tugas, maka indikator telah tercapai

\section{HASIL}

Pada bagian ini diuraikan tentang ketercapaian dari hasil penelitian yang telah dilakukan. Adapaun hasil dari siklus 1 penelitian ini dapat diamati pada tabel. 1 berikut ini:

Tabel. 1 Rekapitulasi Data Penelitian Siklus 1

\begin{tabular}{|c|c|c|c|}
\hline Indikator Ketercapaian & Capaian & Keterangan & Keputusan \\
\hline $\begin{array}{l}\text { Tanggapan Siswa Tentang } \\
\text { Topik Bimbingan }\end{array}$ & $\begin{array}{l}60 \% \text { Memahami dengan } \\
\text { baik topik bimbingan }\end{array}$ & Tercapai & $\begin{array}{l}\text { Tidak diobservasi di } \\
\text { siklus berikutnya }\end{array}$ \\
\hline $\begin{array}{l}\text { Tanggapan Siswa Tentang } \\
\text { Tujuan Bimbingan }\end{array}$ & $\begin{array}{l}68 \% \text { Memahami dengan } \\
\text { baik tujuan bimbingan }\end{array}$ & Tercapai & $\begin{array}{l}\text { Tidak diobservasi di } \\
\text { siklus berikutnya }\end{array}$ \\
\hline $\begin{array}{l}\text { Tanggapan Siswa Atas Materi } \\
\text { Bimbingan }\end{array}$ & $\begin{array}{l}58 \% \text { Menganggap bahwa } \\
\text { materi sesuai dengan } \\
\text { tujuan }\end{array}$ & Tercapai & $\begin{array}{l}\text { Tidak diobservasi di } \\
\text { siklus berikutnya }\end{array}$ \\
\hline $\begin{array}{l}\text { Tanggapan Siswa Terhadap } \\
\text { Metode Bimbingan }\end{array}$ & $\begin{array}{l}84 \% \text { Beranggapan bahwa } \\
\text { metode bimbingan sesuai } \\
\text { dengan masalah yang } \\
\text { mereka hadapai }\end{array}$ & Tercapai & $\begin{array}{l}\text { Tidak diobservasi di } \\
\text { siklus berikutnya }\end{array}$ \\
\hline $\begin{array}{l}\text { Tanggapan Siswa Terhadap } \\
\text { Kegiatan Motivasi Yang } \\
\text { Diberikan Guru Bimbingan } \\
\text { Konseling }\end{array}$ & $\begin{array}{l}86 \% \text { Memahami tujuan } \\
\text { motivasi yang diberikan } \\
\text { konselor }\end{array}$ & Tercapai & $\begin{array}{l}\text { Tidak diobservasi di } \\
\text { siklus berikutnya }\end{array}$ \\
\hline $\begin{array}{l}\text { Mengenali masalah yang } \\
\text { dihadapi }\end{array}$ & $\begin{array}{l}\text { Baru } 36 \% \text { siswa dapat } \\
\text { mengenali masalah }\end{array}$ & Belum Tercapai & $\begin{array}{l}\text { Diobservasi kembali } \\
\text { di siklus } 2\end{array}$ \\
\hline Mengenali penyebab masalah & $\begin{array}{l}\text { Baru } 48 \% \text { siswa dapat } \\
\text { mengenali penyebab } \\
\text { masalah }\end{array}$ & Belum Tercapai & $\begin{array}{l}\text { Diobservasi kembali } \\
\text { di siklus } 2\end{array}$ \\
\hline $\begin{array}{l}\text { Mengenali potensi diri untuk } \\
\text { mengatasi masalah }\end{array}$ & $\begin{array}{l}\text { Baru } 44 \% \text { siswa dapat } \\
\text { mengenali kemampuan } \\
\text { diri dalam mengatasi } \\
\text { masalah }\end{array}$ & Belum Tercapai & $\begin{array}{l}\text { Diobservasi kembali } \\
\text { di siklus } 2\end{array}$ \\
\hline $\begin{array}{l}\text { Dapat menyusun } \\
\text { perencanaan pemecahan } \\
\text { masalah sesuai dengan } \\
\text { masalah, penyebab dan } \\
\text { potensi diri siswa }\end{array}$ & $\begin{array}{l}\text { Baru } 36 \% \text { siswa dapat } \\
\text { menyusun perencanaan } \\
\text { pemecahan masalah } \\
\text { sesuai dengan masalah, } \\
\text { penyebab dan potensi diri } \\
\text { siswa }\end{array}$ & Belum Tercapai & $\begin{array}{l}\text { Diobservasi kembali } \\
\text { di siklus } 2\end{array}$ \\
\hline $\begin{array}{l}\text { Dapat mengorganisir } \\
\text { pemecahan masalah sesuai } \\
\text { dengan masalah yang } \\
\text { dihadapi, penyebab masalah, } \\
\text { dan upaya pemecahan } \\
\text { masalah dengan baik }\end{array}$ & $\begin{array}{l}\text { Baru } 36 \% \text { siswa dapat } \\
\text { mengorganisir } \\
\text { pemecahan masalah } \\
\text { sesuai dengan masalah } \\
\text { yang dihadapi, penyebab } \\
\text { masalah, dan upaya } \\
\text { pemecahan masalah } \\
\text { dengan baik }\end{array}$ & Belum Tercapai & $\begin{array}{l}\text { Diobservasi kembali } \\
\text { di siklus } 2\end{array}$ \\
\hline $\begin{array}{l}\text { Dapat membuat refleksi dari } \\
\text { proses pemecahan masalah } \\
\text { yang dilakukan }\end{array}$ & $\begin{array}{l}\text { Baru } 34 \% \text { siswa dapat } \\
\text { membuat refleksi dari } \\
\text { proses pemecahan } \\
\text { masalah yang dilakukan }\end{array}$ & Belum Tercapai & $\begin{array}{l}\text { Diobservasi kembali } \\
\text { di siklus } 2\end{array}$ \\
\hline
\end{tabular}

Berdasarkan tabel. 1 hasil penelitian siklus satu diketahuai bahwa ketercapaian indikator yang ditetapkan adalah sebanyak adalah 5 indikator dari 11 indikator (5/11x $100 \%=46 \%$ ). Dengan demikian diketahui bahwa belum semua indikator ketercapaian dapat 
dipenuhi dalam penelitian siklus satu, sehingga perlu dilakukann penelitian siklus ke-2. Adapun hasil dari pelaksanaan siklus ke-2 ini dapat diamati pada tabel. 2 berikut ini:

Tabel. 2 Rekapitulasi Data Penelitian Siklus 2

\begin{tabular}{|c|c|c|c|}
\hline Indikator Ketercapaian & Capaian & Keterangan & Keputusan \\
\hline $\begin{array}{l}\text { Mengenali masalah yang } \\
\text { dihadapi }\end{array}$ & $\begin{array}{l}92,5 \% \text { siswa dapat } \\
\text { mengenali masalah }\end{array}$ & Tercapai & $\begin{array}{l}\text { Tidak diobservasi di } \\
\text { siklus berikutnya }\end{array}$ \\
\hline Mengenali penyebab masalah & $\begin{array}{l}95 \% \text { siswa dapat } \\
\text { mengenali penyebab } \\
\text { masalah }\end{array}$ & Tercapai & $\begin{array}{l}\text { Tidak diobservasi di } \\
\text { siklus berikutnya }\end{array}$ \\
\hline $\begin{array}{l}\text { Mengenali potensi diri untuk } \\
\text { mengatasi masalah }\end{array}$ & $\begin{array}{l}90 \% \text { siswa dapat } \\
\text { mengenali kemampuan } \\
\text { diri dalam mengatasi } \\
\text { masalah }\end{array}$ & Tercapai & $\begin{array}{l}\text { Tidak diobservasi di } \\
\text { siklus berikutnya }\end{array}$ \\
\hline $\begin{array}{l}\text { Dapat menyusun } \\
\text { perencanaan pemecahan } \\
\text { masalah sesuai dengan } \\
\text { masalah, penyebab dan } \\
\text { potensi diri siswa }\end{array}$ & $\begin{array}{l}82 \% \text { siswa dapat } \\
\text { menyusun perencanaan } \\
\text { pemecahan masalah } \\
\text { sesuai dengan } \\
\text { masalah, penyebab dan } \\
\text { potensi diri siswa } \\
\end{array}$ & Tercapai & $\begin{array}{l}\text { Tidak diobservasi di } \\
\text { siklus berikutnya }\end{array}$ \\
\hline $\begin{array}{l}\text { Dapat mengorganisir } \\
\text { pemecahan masalah sesuai } \\
\text { dengan masalah yang } \\
\text { dihadapi, penyebab masalah, } \\
\text { dan upaya pemecahan } \\
\text { masalah dengan baik }\end{array}$ & $\begin{array}{l}\text { 96\% siswa dapat } \\
\text { mengorganisir } \\
\text { pemecahan masalah } \\
\text { sesuai dengan masalah } \\
\text { yang dihadapi, } \\
\text { penyebab masalah, dan } \\
\text { upaya pemecahan } \\
\text { masalah dengan baik }\end{array}$ & Tercapai & $\begin{array}{l}\text { Tidak diobservasi di } \\
\text { siklus berikutnya }\end{array}$ \\
\hline $\begin{array}{l}\text { Dapat membuat refleksi dari } \\
\text { proses pemecahan masalah } \\
\text { yang dilakukan }\end{array}$ & $\begin{array}{l}86 \% \text { siswa dapat } \\
\text { membuat refleksi dari } \\
\text { proses pemecahan } \\
\text { masalah yang dilakukan }\end{array}$ & Tercapai & $\begin{array}{l}\text { Tidak diobservasi di } \\
\text { siklus berikutnya }\end{array}$ \\
\hline
\end{tabular}

Berdasarkan tabel. 2 diketahui bahwa tingkat ketercapaian dalam siklus ke-2 ini adalah 6 indikator dari 6 indikator $(6 / 6 \times 100 \%=100 \%$ (seluruh indikator ketercapaian telah dicapai). Dengan ketercapaian ini maka dapat dikatakan bahwa seluruh kriteria yang ditetapkan dalam penelitian telah tercapai, dengan kata lain siklus penelitian tindakan pada bimbingan dan konseling ini berhenti sampai pada siklus dua saja. Berdasarkan ketercapaian kriteria, penelitian ini menunjukan bahwa pelaksanan layanan bimbingan dengan teknik PBI dapat diterpkan dalam meningkatkan kemampuan menyelesaikan masalah belajar siswa SMK.

\section{PEMBAHASAN}

Berdasarkan hasil penelitian maka diketahui bahwa layanan bimbingan dengan menggunakan teknik Problem-based Introduction (PBI) dapat diterapkan untuk meningkatkan kemampu memnyelesaikan masalah siswa SMK. Pelaksanaan penelitian ini dapat dijelaskan sebagai berikut: (1) Pada siklus pertama, meskipun siswa telah memahami penjelasan yang diberikan guru bimbingan konseling tentang topik bimbingan, tujuan bimbingan, materi bimbingan dan metode bimbingan, tetapi siswa belum dapat mengenali masalah yang dihadapi, penyebab masalah yang dihadapi, dan mereka juga belum dapat mengenali potensi dirinya untuk mengatasi masalah yang dihadapi. (2) Siswa juga belum dapat mengorganisasikan 
masalah, penyebab masalah, dan potensi yang dimiliki ke dalam suatu perencanaan untuk menyelesaikan masalah kesulitan belajarnya. (3) Pada siklus kedua setelah diberikan bimbingan dan motivasi, siswa dapat mengenali masalah yang dihadapi, penyebab masalah yang dihadapi, dan mereka juga dapat mengenali potensi dirinya untuk mengatasi masalah yang dihadapi. Mereka juga telah dapat mengorganisasikan masalah, penyebab masalah, dan potensi yang dimiliki untuk menyelesaikan masalah yang dihadapi ke dalam suatu kegiatan sebagai upaya mengatasi kesulitan belajarnya.

Dalam kegiatan penelitian ini, peneliti memilih layanan bimbingan yang dinilai lebih fleksibel, erat dengan kegiatan pembelajaran serta asumsinya layanan yang diberikan adalah untuk semua siswa, tidak hanya yang bermasalah saja. Layanan bimbingan juga diorientasikan untuk layanan pada siswa dengan jangkauan yang lebih luas dan sesuai dengan karakteristiknya, layanan ini digunakan untuk upaya pencegahan dan pengembangan potensi siswa. Dalam hal ini peneliti berusaha mengembangkan atau meningkatkan kemampuan siswa dalam menyelesaikan masalah belajarnya. Dengan kata lain peneliti menilai pemilihan layanan bimbingan adalah tepat.

Lebih khusus kemampuan yang ingin dikembangkan peneliti adalah kemampuan penyelesaian masalah belajar siswa SMK, maka peneliti juga harus memilih teknik yang relevan dengan potensi siswa yang akan dikembangkan. Peneliti memilih teknik problem-based introduction (PBI) yang memang memiliki spesifikasi dalam pengembangan kemampuan problem solving siswa. Beberapa literatur menunjukan bahwa teknik ini cocok digunakan dalam seting pembelajaran. Munir (2012) menggunakan model pembelajaran problem based introduction (PBI) dalam meningkatkan kemampuan mahasiswa mendesain PCB. Begitu juga penelitian yang dilakukan oleh Hasan (2015) yang membuktikan bahwa penggunaan problem based introduction (PBI) dapat meningkatkan prestasi belajar fisika siswa SMAN 1 Sumenep. Aquirista (2011) juga membuktikan bahwa penerapan model pembelajaran problem based introduction (PBI) dapat meningkatkan aktivitas belajar PKn Siswa kelas V SDN Bareng 3 Kota Malang. Dari beberapa penelitian tersebut membangun asusmsi peneliti bahwa teknik ini juga bisa diterapkan dalam layanan bimbingan yang kharaktersitiknya hampir sama dengan kegiatan pembelajaran. Dengan teknik PBI ini siswa dibantu untuk dapat responsive pada masalah belajar yang sedang dihadapi atau mungkin dihadapi siswa dimasa depan. Teknik ini memberikan kerangka dan langkah yang dinilai sistematis dalam menelaah berbagai masalah, tidak terkecuali masalah belajar siswa. Secara sederhana siswa diajak untuk memahami suatu masalah dan dimotivasi untuk mencari solusi yang dinilai relevan. Ditahap akhir siswa diajak untuk mengevaluasi dan merefleksi berbagai alternative pemecahan yang dinilai paling tepat. Dengan langkah-langkah yang diajarkan oleh konselor kepada siswa tersebut maka siswa menjadi terarah dan terbiasa dalam menyelesaikan masalahnya, selanjutnya tinggal diarahkan untuk membawa diseting kehidupan sehari-hari siswa terutama dalam mengatasi berbagai masalah belajarnya.

\section{KESIMPULAN DAN SARAN}

Berdasarkan paparan hasil penelitian yang telah dilakukan maka dapat disimpulkan bahwa layanan bimbingan dengan teknik problem-based introduction dapat diterpkan untuk 
meningkatkan kemampuan menyelesaikan masalah belajar siswa SMK. Selanjutnya peneliti merekomendasaikan beberapa saran antara lain: 1) Kombinasi layanan bimbingan dengan teknik PBI ini dapat diterapkan oleh konselor khususnya di sekolah menengah kejuruan untuk meningkatkan kemampuan menyelesaikan masalah belajarnya; 2) Pada sekolah, problem belajar siswa haruslah mendapat perhatian khusus, sehingga penerapan PBI pada mata pelajaran lainya juga disarankan; 3) Pada peneliti selanjutnya, kombinasi jenis layanan dan teknik lainya juga dapat diterapkan dalam upaya meningkatkan kemampuan siswa dalam menyelesaikan masalah siswa SMK; 4) Penerapan layanan bimbingan dengan teknik PBI juga dapat dicoba untuk mengembangkan aspek psikologis lainya, selain kemampuan pemecahan masalah belajar siswa; 5) Penggunaan metode penelitian lainya selain PTBK (penelitian tindakan dalam BK) juga dapat diterapkan peneliti selanjutnya misalnya penggunaan penelitian eksperimen dan single subject design (SSD) untuk menguji keefektifan teknik layanan bimbingan dengan teknik $\mathrm{PBI}$ atau penggunaan metode penelitian lainya.

\section{DAFTAR RUJUKAN}

Afflerbach, P., Cho, B. Y., \& Kim, J. Y. (2015) Conceptualizing and Assessing High-Order Thinking in Reading. Theory into Practice, 54(3) 203-212. https://doi.org/10.1080/00405841.2015.1044367.

Arikunto, Suharsimi. 2006. Penelitian Tindakan Kelas. Jakarta: Bumi Aksara.

Aquirista, F. 2011. Penerapan Model Pembelajaran Problem Based Introduction (PBI) untuk Meningkatkan Aktivitas dan Hasil Belajar PKn Slswa Kelas V SDN Bareng 3 Kota Malang. Skripsi tidak diterbitkan. Malang: FIP UM.

Dahar, R. W. 1998. Teori-teori Belajar. Jakarta: Departemen Pendidikan dan Ke-budayaan, Dirjen Dikti, P2LPTK.

Fauziah. (2017). Penerapan Pendekatan Creative Problem Solving Terhadap Peningkatan Kemampuan Pemecahan Masalah Matematik Siswa Kelas XII RPL B SMK Negeri Cimahi. Jurnal IImiah UPT P2M STKIP Siliwangi, 4(2) $\quad$ 1-6. https://doi.org/10.22460/p2m.v4i2pq-6.635.

Hasan, Z. (2015) Meningkatkan Prestasi Belajar Fisika Siswa Melalui Penggunaan Model Pembelajaran Problem Based Introduction di Kelas X/MIA-4 SMAN 1 Sumenep Tahun Pelajaran 2013/2014. LENSA (Lentera Sains): Jurnal Pendidikan IPA 5(1), 3550. https://doi.org/10.24929/fkip.v5i1.225.

Hitipeuw, Imanuel. 2009. Belajar \& Pembelajaran. Malang: Fakultas IImu Pendidikan Universitas Negeri Malang.

Majid, Abdul. 2008. Perencanaan Pembelajaran. Bandung: PT Remaja Rosdakarya.

Munir, M. (2012) Model Pembelajaran Problem Based Introduction (PBI) dalam Desain Printed Circuit Board (PCB) Bagi Mahasiswa Prodi T. Elektronika (D3) dan P.T. Elektronika (S1) FT UNY. Jurnal Pendidikan Teknologi dan Kejuruan 21(1), 60-66. https://doi.org/10.21831/jptk.v21i1.3340.

Mustaji. 2018. Pembelajaran Berbasis Masalah. Surabaya: Absolute Media. 
Nora, Muliyandari. 2011. Penerapan Model Pembelajaran Problem Based Introduction (PBI) untuk Meningkatkan Hasil Belajar IPA siswa Kelas VI di SDN Purwantoro 2 Kota Malang. Skripsi tidak diterbitkan. Malang: FIP UM.

Safitri, R. R., Atrup, A., \& Hanggara, G. S. (2018). Problem Solving dalam Meningkatkan Kemampuan Berfikir Kritis Siswa SMK. Nusantara of Research : Jurnal Hasil-Hasil Penelitian Universitas Nusantara PGRI Kediri (e-journal), 5(2), 83-88. https://doi.org/10.29407/nor.v5i2.13079.

Senjaya, Wina. 2008. Strategi Pembelajaran; Berorientasi Standard Proses Pendidikan. Jakarta: Kencana Prenada Media Group.

Sugiyanto. 2009. Model-model Pembelajaran Inovatif. Surakarta: Panitia Sertifikasi Guru Rayon 13 FKIP UNS Surakarta. 